SHS Web of Conferences 10, 00045 (2014)

DOI: $10.1051 /$ shsconf/20141000045

C Owned by the authors, published by EDP Sciences, 2014

\title{
Changes of indicators of social intelligence for substance use disorders patients: Before Minnesota program, after program treatment and six months later
}

\author{
V. Sudraba ${ }^{1}$, K. Martinsone ${ }^{2}$, and V. Arnis ${ }^{2}$ \\ ${ }^{1}$ Riga Centre of Psychiatry and Addiction Disorders, Latvia \\ ${ }^{2}$ Rìga Stradiòš University, Latvia
}

\begin{abstract}
Aim: to estimate indicator changes of Social Intelligence (SI) of substance use disorders (SUD) patients before Minnesota program (MP), after MP treatment and six months later. Material and methods: The first measurement was done at the beginning of treatment in Minnesota program (MP), the second measurement was done, when program was finished. The third measurement was done 6 months after treatment. Selection of research was composed by 204 respondents with diagnosis of SUD (F10.2 - F19.2, ICD10), average age 36,9 $(\mathrm{SD}=11,1) ; 61.3 \%$ - male; $79.4 \%$ - alcoholics. Instruments: Trømso Social Intelligence Scale, TSIS (Silvera, Martinussen, Dahl, 2001). Scale of SI consists of 21 items, building 3 factors: Social information processing (SP), social skills (SS), social awareness (SA). Descriptive and ANOVA was used for data processing. Results and Conclusions. After data of descriptive statistic, SI indicators increase for MP patients in all 3 scales after treatment and 6 months later. In comparing SI results for MP patients both male and female, in all three measurements, descriptive and conclusive statistical data (Bonferroni test) show that statistically significant time effect $(\mathrm{p} \leq 0.05)$ appears in the total SI for men, furthermore, the changes occurred between the 1 st and $3 \mathrm{rd}$ measurements.
\end{abstract}

\section{Introduction}

Researchers have come to an unequivocal conclusion that social intelligence is a multidimensional construct (Vasilova, Baumgartner, 2004). A general standpoint stemming from the many theories is that from today's perspective the concept of social intelligence encompasses perceptual, cognitive-analytical and behavioural (skills) components (Björkqvist et al., 2000) which determine individual differences in social behaviour - the public manifestations of personality - and is the product of individual differences used by individuals in their social interactions (Kihlstrom, Cantor, 2000).

Norwegian researchers D.H. Silvera, M. Martinussen and T. Dahl (Silvera et al., 2001) developed a test for measuring social intelligence - the Troms $\phi$ Social Intelligence Scale which was also used in the present study. The authors identified three SI components: (a) social information processing, (b) social skills and (c) social awareness.

Social information processing describes cognitive processes involved in social interaction: the awareness and acceptance of social situations; the ability to listen to others and fully understand implied

This is an Open Access article distributed under the terms of the Creative Commons Attribution License 4.0, which permits unrestricted use, distribution, and reproduction in any medium, provided the original work is properly cited. 


\section{SHS Web of Conferences}

or partially expressed thoughts and feelings; the defining and setting of targets, the search for feedback or social solutions (Silvera et al., 2001; Lopes et al., 2004; Meijs et al., 2010).

Social skills encompass responsibility, self-control, persistence, cooperation, individual's ability to be a member of a group or team. A high social intelligence is associated with the ability to find appropriate means of communication with various people from all walks of life in various situations; these individuals are characterized by wide repertoire of social roles and neuroplasticity in role playing (Silvera et al., 2001; Meijs et al., 2010).

Social awareness describes the ability to recognize culture and values related aspects of different social groups and how these aspects influence individual's actions and behaviour (Silvera et al., 2001; Meijs et al., 2010). Social awareness includes the ability to empathy.

Despite being a widely studied area, it is still not clear what determines the formation, development and various manifestations of social intelligence in individuals of different social groups.

As pointed out by Ham and Garcia (Ham, Garcia, 2010), social intelligence skills are closely related to alcohol and drug use - the lower the skills, the higher the risk for an individual to use drugs and vice versa - substance abuse leads to impairments in social intelligence skills. Similar observation was made by American researchers (Scheier et al., 1999). The study analysed to what degree selfconfidence and related social skills, personal competence as well as refusal efficacy could predict alcohol abuse. Males are at a higher risk for both poor refusal skills and higher alcohol involvement. Adolescents characterized by poorly developed social skills reported lower refusal efficacy, lower level of education, poor competence and more intense alcohol use (Scheier et al., 1999). Poor refusal efficacy was associated with more risk-taking, lower level of education, less developed competence and more intense alcohol use. Higher personal competence was associated with lower alcohol use but had no long-term effects on alcohol use (Scheier et al., 1999).

The analysis of substance use disorders (SUD) patients revealed gender differences in social intelligence skills and competence. In a research dealing with substance use in schoolchildren it was found that boys' smoking and girls' alcohol consumption did not prevent from reaching a sufficiently high level of social skills. However, a lower level of social information processing was associated with boys' smoking and a lower level of social awareness was associated with boys' alcohol consumption (Orosova, Gajdošova, 2009).

It has been established that there exist structural and functional brain changes, a complex interplay between cognitive processes, brain maturation, psychopathology and psychoactive substance use. Neurotoxic effects of psychoactive substances on brain lead to cognitive impairments in which memory dysfunction is playing an important role (Yücel et al., 2007; Robbins et al., 2008; Schoenbaum, Shaham, 2008) and thus result in thought and perceptual disorders which hamper the ability to assess situation in a realistic way. These deficits could be one of the reasons why drug addicts and alcoholics perceive the reality around them as exaggeratedly idealized denying any possibility of deficiencies or as potentially hostile and threatening thus further exhibiting their inability to properly assess the reality around them and swinging from one extreme to another.

The information available suggests that psychoactive substance (PAS) use and addiction have an impact on psychosocial functioning of individuals. Therefore the following research question is put forth: are there any differences in SUD patients' social intelligence indicators after completing treatment in Minnesota Program and 6 month later?

\section{Materials and methods}

Data collection was undertaken between January 1, 2010 and October 31, 2011. From the MP patients repeatedly data from questionnaire (SI) was gathered via 3 measurements: (a) in beginning MP (1st measurement), (b) completing MP (2nd), (c) 6 months after MP treatment (3rd). 
Int. Conf. SOCIETY. HEALTH. WELFARE.

\section{Research settings}

Public limited liability company "Riga Centre of Psychiatry and Addiction Disorders", inpatient department for addiction disorders - Minnesota Program (MP). The Minnesota Program Department (12 beds) is merged with the Motivational Department therefore some patients may undergo only motivational course (7-12 days) without proceeding to Minnesota Program (28 days). Patients without at least 5 days of uncontrolled psychoactive substance use or patients who have completed the detoxification course are admitted.

\section{Inclusion criteria:}

Patients diagnosed with a substance use disorders (F10.2-F19.2) according to the ICD-10 classification; patients who are at least 18 years old; patients having no acute condition; patients who understand Latvian. The decision to accept or refuse participation in this study did not affect the quality of treatment provided.

\section{Exclusion criteria:}

Patients who either refuse to fill out the patient questionnaire and/or SI questionnaire and/or EI questionnaire or fill them out incompletely; in-patients who undergo only to the motivational course.

\section{Participants}

Out of 303 patients who received treatment in the department during the respective period of time, 212 patients matched the inclusion criteria, 204 respondents took part in the first measurement (96.2\%), $2^{\text {nd }}-157(77.0 \%), 3^{\text {rd }}-109$ patients $(53.4 \%)$. Respondents $(n=204)$ profile: aged 18 to 65 , mean age $36.9 \pm 11.1$; by gender: 125 men $(61.3 \%)$, 79 women $(38.7 \%)$; by addiction type: 162 alcoholics (79.4\%), 42 drug abusers (20.6\%) of which F11 - 5 (11.9\%), F15 - 9 (21.4\%), F19 - 28 (66.7\%). Only the SI data of those respondents who took part in all 3 measurements were analysed.

Table 1 depicts the comparison of respondents who continued and discontinued participation in the study by several variables (gender, age, education, employment, marital status, addiction recognition). Statistically significant differences were found only in respect to education, namely, respondents with higher education more often continued their participation in the study.

\section{Research Instrument}

Tromsø Social Intelligence Scale, TSIS (Silvera et al., 2001); adapted in Latvia by Kuznecova, Slosberga (Kuznecova, Slosberga, 2006). One factor (social skills) rates social activity, the two remaining - social cognition. The Social intelligence survey is made up of 21 assertions, 7 in each scale, creating 3 scales: (1) Social information processing scale (SIP); (2) Social skills (SS); (3) Social awareness (SA).

Responses are evaluated via a 7-level Likert Scale, with 1 being "strongly disagree", and 7 "strongly agree". Points are summed up, but only after re-coding questions with a negative meaning. The more points a respondent receives, the higher the SI indicator.

The internal consistence of Troms $\emptyset$ scale was determined by calculating Kronbah alpha coefficients which range from 0.72 to 0.80 , correspond to the coefficients of internal consistence obtained in original pilot study $(0,72-0,85)$ (Silvera et al., 2001) and are higher than those of the pilot validation study (0.60-0.67) (Kuzņecova, Šlosberga, 2006). 


\section{SHS Web of Conferences}

Table 1. A Comparison of Minnesota Program Respondents who Continued and Discontinued Participation in the Study.

\begin{tabular}{|c|c|c|c|c|c|c|}
\hline $\begin{array}{l}\text { Socio- } \\
\text { demographic data }\end{array}$ & & $\begin{array}{l}\text { Completed } \\
\mathrm{n}(\%)\end{array}$ & $\begin{array}{l}\text { Failed to } \\
\text { complete } \\
\mathrm{n}(\%)\end{array}$ & $\begin{array}{l}\% \text { of those } \\
\text { who } \\
\text { completed }\end{array}$ & $\begin{array}{l}\% \text { of those } \\
\text { who failed } \\
\text { to complete }\end{array}$ & p-value \\
\hline \multirow{2}{*}{ Gender } & Males & $73(58.4)$ & $52(41.6)$ & 67.0 & 54.7 & \multirow{2}{*}{$0.074^{\mathrm{a}}$} \\
\hline & Females & $36(45.6)$ & $43(54.4)$ & 33.0 & 45.3 & \\
\hline Mean age & & $37.3 \pm 10.6$ & $36.4 \pm 11.7$ & & & $0.591^{\mathrm{b}}$ \\
\hline \multirow{4}{*}{ Education } & Primary education & $21(40.4)$ & $31(59.6)$ & 19.3 & 32.6 & \multirow{4}{*}{$0.002^{c}$} \\
\hline & Secondary education & $27(49.1)$ & $28(50.9)$ & 24.8 & 29.5 & \\
\hline & $\begin{array}{l}\text { Secondary } \\
\text { vocational education }\end{array}$ & $37(56.9)$ & $28(43.1)$ & 33.9 & 29.5 & \\
\hline & Higher education & $24(74.2)$ & $8(25.8)$ & 22.0 & 8.4 & \\
\hline \multirow{5}{*}{ Marital status } & Married & $37(66.1)$ & $19(33.9)$ & 33,9 & 20.0 & \multirow{5}{*}{$0.220^{c}$} \\
\hline & Divorced & $13(40.6)$ & $19(59.4)$ & 11.9 & 20.0 & \\
\hline & Widow(-er) & $5(55.6)$ & $4(44.4)$ & 4.6 & 4.2 & \\
\hline & Single & $24(49.0)$ & $25(51.0)$ & 22.0 & 26.3 & \\
\hline & Civil partnership & $30(51.7)$ & $28(48.3)$ & 27.5 & 29.5 & \\
\hline \multirow{2}{*}{ Age of first use } & Alcohol & $15.1 \pm 3.5$ & $14.7 \pm 3.3$ & & & $0.454^{\mathrm{d}}$ \\
\hline & Drugs & $18.8 \pm 4.0$ & $17.4 \pm 3.8$ & & & $0.143^{\mathrm{b}}$ \\
\hline \multirow{2}{*}{$\begin{array}{l}\text { Addiction } \\
\text { recognition }\end{array}$} & Alcohol addiction & $94(52.5)$ & $85(47.5)$ & 86.2 & 89.5 & $0.482^{\mathrm{a}}$ \\
\hline & Drug addiction & $20(50.0)$ & $20(50.0)$ & 18.3 & 21.1 & $0.628^{\mathrm{a}}$ \\
\hline
\end{tabular}

${ }^{\text {a }}$ By $\chi^{2}$ test.

${ }^{\mathrm{b}}$ By Student's t- test.

${ }^{\mathrm{c}}$ By Spearman's correlation test.

${ }^{\mathrm{d}}$ By Mann-Whitney test.

Table 2. Three Measurements of Descriptive Statistical Indicators of Social Intelligence for MP Respondents.

\begin{tabular}{|c|c|c|c|c|c|c|c|c|c|c|c|c|}
\hline \multirow[t]{3}{*}{ Scales } & \multicolumn{4}{|c|}{ Measurement 1} & \multicolumn{4}{|c|}{ Measurement 2} & \multicolumn{4}{|c|}{ Measurement 3} \\
\hline & \multicolumn{2}{|c|}{ Males $(n=73)$} & \multicolumn{2}{|c|}{ Females $(n=36)$} & \multicolumn{2}{|c|}{ Males $(\mathrm{n}=73)$} & \multicolumn{2}{|c|}{ Females $(\mathrm{n}=36)$} & \multicolumn{2}{|c|}{ Males $(n=73)$} & \multicolumn{2}{|c|}{ Females $(\mathrm{n}=36)$} \\
\hline & $\mathrm{M}$ & SD & $\mathrm{M}$ & SD & $\mathrm{M}$ & SD & $\bar{M}$ & SD & $\mathrm{M}$ & SD & $\mathrm{M}$ & SD \\
\hline SIP & 30.66 & 7.68 & 30.0 & 7.85 & 30.9 & 7.19 & 30.22 & 7.43 & 33.21 & 7.19 & 32.03 & 8.03 \\
\hline SS & 29.21 & 9.04 & 29.89 & 8.59 & 30.16 & 8.39 & 29.39 & 7.99 & 32.84 & 9.09 & 30.81 & 8.40 \\
\hline SA & 29.14 & 7.87 & 27.56 & 7.80 & 29.88 & 7.36 & 27.92 & 7.37 & 32.51 & 6.85 & 30.53 & 7.03 \\
\hline Total SI & 89.00 & 18.89 & 87.53 & 17.71 & 91.03 & 18.20 & 87.53 & 16.02 & 98.55 & 17.50 & 93.36 & 18.79 \\
\hline
\end{tabular}

\section{Results}

In order to assess changes in the three measurements for MP patients calculations of descriptive statistical indicators (see Table 2) and simple dispersion analysis for repeated measurements taking into account Bonferroni test (see Table 3 ) was done.

The results of the descriptive statistics show a tendency for mean indicators to increase in all 3 measurements of all 3 scales and the total SI in males. However, in the female group there is a tendency for mean indicators to decrease in measurement 2 of the social skills scale and to remain unchanged in the total SI.

In comparing SI results for MP patients both male and female, in all three measurements, descriptive and conclusive statistical data (Bonferroni test) show that statistically significant time effect $(\mathrm{p} \leq 0.05$ ) 
Int. Conf. SOCIETY. HEALTH. WELFARE.

Table 3. Three Measurements of Conclusive Statistical Indicators of Social Intelligence for MP Respondents.

\begin{tabular}{|c|c|c|c|c|c|c|}
\hline \multirow[t]{2}{*}{ Scales } & \multicolumn{3}{|l|}{ Males } & \multicolumn{3}{|l|}{ Females } \\
\hline & $\begin{array}{l}\text { F change } \\
\text { in time }\end{array}$ & $\begin{array}{l}\text { Bonferron } \\
\text { test }^{1}\end{array}$ & $\begin{array}{l}\text { Bonferroni } \\
\text { test }^{2}\end{array}$ & $\begin{array}{l}\text { F change in } \\
\text { time }\end{array}$ & $\begin{array}{l}\text { Bonferroni } \\
\text { test }^{1}\end{array}$ & $\begin{array}{l}\text { Bonferroni } \\
\text { test }^{2}\end{array}$ \\
\hline SIP & 1.84 & -0.86 & -2.19 & 0.39 & -1.17 & -0.58 \\
\hline SS & 2.53 & -0.37 & -3.10 & 0.17 & -0.18 & -0.99 \\
\hline SA & 1.83 & -1.17 & -1.10 & 3.19 & -1.26 & -2.92 \\
\hline Total SI & $3.63^{*}$ & -2.40 & -6.39 & 1.25 & -2.60 & -4.49 \\
\hline
\end{tabular}

appears in the total SI for men (see Table 3), furthermore, the changes occurred between the 1st and 3rd measurements. The remaining results did not show any statistically significant changes or differences $(\mathrm{p}>0.05)$.

\section{Discussion}

The analysis of the results on SI changes for MP patients before Minnesota Program, after program treatment and six month later attests that irrespective of the tendency of SI mean indicators to grow in male and female respondents for all scales, statistically significant changes are found only in the total SI indicator of male respondents. It means that men's ability to understand themselves and others as well as to predict their behaviour has improved. The data from other research studies suggest that psychotherapeutic interventions improve patients' psychosocial functioning which is based on the cognition, emotional and social experience acquired by patients during MP (Dawson et al., 2005; Dawson et al., 2007). The question remains why no statistically significant changes were observed in female respondents. This can potentially be explained by the findings of other researchers that psychoactive substances cause more severe mental health complications in women (Hernandez-Avila et al., 2004), that SUD women have a tendency to mention external problems underestimating internal problems (Plant et al., 2009), that female alcohol addicts are more often diagnosed with depressive mood (Walter et al., 2003) and that female SUD are characterized by more rapid cerebral atrophy development (Hommer et al., 2001; Mann et al., 2005; Maurage et al., 2008). Furthermore, the fact that SUD women are more often married with addictive and aggressive partners (Witkiewitz, 2005; Walitzer, Dearing, 2006), namely, persons with more severe psychosocial functioning impairments in terms of emotional and social performance, can point to more severe psychosocial functioning impairments of SUD women themselves. However, further research is required to find out the reasons for gender differences in the changes of indicators.

\section{Limitations}

The use of the available sample should be mentioned as a limitation of the study. Patient sampling was performed by asking all the patients who met the inclusion criteria to participate in the study. However, the high rates of withdrawal from the study were due to the lack of patient compliance and cooperation, the fact that SI questionnaires had to be completed in Latvian as well as difficulties in repeating the measurement in 6 months. Nonetheless, it is important to note that no statistically significant differences were observed in the socio-demographic data of respondents who withdrew from the study and those who continued their participation.

\section{Conclusions}

Although the study used a psychometrically validated SI scale, it is still a self-assessment questionnaire and taking into account the personality structure of SUD patients, their difficulties in adequately 


\section{SHS Web of Conferences}

assessing the reality and the lack of compliance, this might have influenced the results obtained. Statistically significant changes are observed only in male respondents. The results show an increase in SI indicators 6 months after the treatment as compared to the pre-treatment data. Only a tendency for increase in SI indicators is observed in female respondents. However, further research is required to compare the results with the data of control group as well as to analyze the SUD patient data by addiction type.

\section{References}

[1] Björkqvist, K., Österman, K., Kaukiainen, A. (2000). Social intelligence - empathy = aggression? Aggress. Violent. Beh. 5(2), 191-200

[2] Dawson, D.A., Goldstein, R.B., Grant, B.F. (2007). Rates and correlates of relapse among individuals in remission from DSM-IV alcohol dependence: a 3-year follow-up. Alcohol. Clin. Exp. Res. 31(12), 2036-2045

[3] Dawson, D.A., Grant, B.F., Stinson, F.S., Chou, P.S., Huang, B., Ruan, W.J. (2005). Recovery from DSM-IV alcohol dependence: United States, 2001-2002. Addiction. 100(3), 281-292

[4] Ham, L.S., Garcia, T.A. (2010). Assessment of Social Skills in Substance Use Disorders. In Nangle, D.V., Hansen, D.J., Erdley, C.A., Norton, P.J. (eds), Practitioner's Guide to Empirically Based Measures of Social Skills. New York: Springer Science+Business Media

[5] Hernandez-Avila, C.A., Rounsaville, B.J., Kranzler, H.R. (2004). Opioid-, cannabis- and alcoholdependent women show more rapid progression to substance abuse treatment. Drug. Alcohol. Depen. 74(3), 265-272

[6] Hommer, D.W., Momenan, R., Kaiser, E., Rawlings, R.R. (2001). Evidence for a gender-related effect of alcoholism on brain volumes. Am. J. Psychiatry. 158, 198-204

[7] Kihlstrom, J.F., Cantor, N. (2000). Social Intelligence. In Sternberg, R.J. (ed), Handbook of intelligence, $2^{\text {nd }}$ ed. Cambridge, UK: Cambridge University Press.

[8] Kuzņecova, I., Šlosberga, I. (2006). Tromso sociālā intelekta aptaujas adaptācija Latvijāa. [Adaptation of Tromso Social Intelligence Test in Latvia]. Nepublicēts maǵsistra darbs. Rīga, (in Latvian)

[9] Lopes, P.N., Brackett, M.A., Nezlek, J.B., Schutz, A., Sellin, I., Salovey, P. (2004). Emotional intelligence and social interaction. Pers. Soc. Psychol. B. 30, 1018-1034. DOI:10.1177/0146167204264762

[10] Mann, K., Ackermann, K., Croissant, B., Mundle, G., Nakovics, H., Diehl, A. (2005). Neuroimaging of gender differences in alcohol dependence: are women more vulnerable? Alcohol. Clin. Exp. Res. 29, 896-901

[11] Maurage, P., Philippot, P., Joassin, F., Pauwels, L., Pham, T., Prieto, E.A., Palmero-Soler, E., Zanow, F., Campanella, S. (2008). The auditory-visual integration of anger is impaired in alcoholism: an event-related potentials study. J. Psychiatry. Neurosci. 33(2), 111-122.

[12] Meijs, N., Cillessen, A.H.N., Scholte, R.H.J., Segers, E., Spijkerman, R. (2010). Social Intelligence and Academic Achievement as Predictors of Adolescent Popularity. J. Youth Adolesc. 39(1), 62-72. DOI: 10.1007/s10964-008-9373-9

[13] Orosova, O., Gajdošova, B. (2009). The association of social intelligence factors, normative expectations, and perceived accessibility with legal drug. Adiktologie. 9(4), 204-211

[14] Plant, M.A., Plant, M.L., Miller, P., Gmel, G., Kuntsche, S. (2009). The Social Consequences of Binge Drinking: A Comparison of Young Adults in Six European Countries. J. Addict. Dis. 28(4), 294-308

[15] Robbins, T.W., Ersche, K.D., Everitt, B.J. (2008). Drug Addiction and the Memory Systems of the Brain. Ann. NY. Acad. Sci. 1141, 1-21 
Int. Conf. SOCIETY. HEALTH. WELFARE.

[16] Scheier, L.M., Botvin, G.J., Diaz, T., Griffin, K.W. (1999). Social skills, competence, and drug refusal efficacy as predictors of adolescent alcohol use. J. Drug. Educ. 29(3), 251-278

[17] Schoenbaum, G., Shaham, Y. (2008). The Role of Orbitofrontal Cortex in Drug Addiction: A Review of Preclinical Studies. Biol. Psychiat. 63(3), 256-262

[18] Silvera, D.H., Martinussen, M., Dahl T. (2001). The Tromso Social Intelligence Scale, a selfreport measure of social intelligence. Scand. J. Psychol. 42, 313-319

[19] Vasilova, K., Baumgartner, F. (2005). Why is Social Intelligence Difficult to Measure? http://www.saske.sk/cas/archiv/4-2005/studia_vasilova-baumgartner.html [accessed 2010 Jun 25]

[20] Walitzer, K.S., Dearing, R.L. (2006). Gender differences in alcohol and substance use relapse. Clin Psychol Rev. 26(2), 128-148

[21] Walter, H., Gutierrez, K., Ramskogler, K., Hertling, I., Dvorak, A., Lesch, O.M. (2003). Genderspecific differences in alcoholism: implications for treatment. Arch. Women. Ment. Health. 6(4), 253-258

[22] Witkiewitz, K. (2005). Defining Relapse from a Harm Reduction Perspective. J. Evid-Bas. Soc. Work. 1-2, 191-206

[23] Yücel, M., Lubman, D.I., Solowij, N., Brewer, W.J. (2007). Understanding Drug Addiction: a neuropsychological perspective. Aust. NZ. J. Psychiat. 41(12), 957-968 